\title{
Management Practices and Employee Engagement in the Workplace: A Qualitative-Phenomenological Study
}

\author{
Marivic B. Peñaflor, Roel D. Juevesa \\ BS in Accountancy Program, Ramon Magsaysay Memorial Colleges, General Santos City, Philippines \\ Email: marivicpenaflor.bsa@gmail.com
}

How to cite this paper: Peñaflor, M. B., \& Juevesa, R. D. (2021). Management Practices and Employee Engagement in the Workplace: A Qualitative-Phenomenological Study. Open Journal of Business and Management, 9, 288-308.

https://doi.org/10.4236/ojbm.2021.91016

Received: December 9, 2020

Accepted: January 23, 2021

Published: January 26, 2021

Copyright $\odot 2021$ by author(s) and Scientific Research Publishing Inc. This work is licensed under the Creative Commons Attribution International License (CC BY 4.0).

http://creativecommons.org/licenses/by/4.0/

(c) (i) Open Access

\begin{abstract}
The purpose of this phenomenological study was to understand the experiences of the employees in terms of job engagement as a result of their management practices in the workplace. It also described their coping mechanisms on the challenges posed by management practices to remain engaged in the organization. The qualitative-phenomenological research design was utilized where 6 rank and file employees of the medium enterprises in General Santos City were picked to undergo an in-depth interview. The results of the interview were transcribed, translated, and coded to produce themes. As regards to experiences to management practices, the following were the themes: trusting employees, clear communication, teamwork and collaboration, the inconsistency of policy implementation, and lack of recognition. As to their coping mechanisms to remain engage in the job, the themes include acceptance of organizational culture, presence of family support, proactive thinking and self-motivation, and job focus and commitment. As to their insights for having highly engaged employees, the themes generated were valuing employee, leadership by example, a proper channel of communication, and authentic management recognition.
\end{abstract}

\section{Keywords}

Employee Engagement, Management Practices, Phenomenology, Qualitative Study

\section{Introduction}

Employees play a very important role in the organizational success (Henry, 1994). Even how sophisticated the technology is, the employee is the one working and operating every area in the workplace thereby leading to the achieve- 
ment of organizational objectives. Medina (2011) stated that employees are the true asset of the organization. It is because through them office deliverables can be achieved effectively and efficiently (Manzoor, 2012).

However, it is to be noted that employees' performance is sometimes dependent on the type of management and the practices the organization had. As mentioned by Luenendonk (2017) \& Kirkeby (2000), management practices refer to any methods and innovations the managers applied in the workplace to achieve efficiency. Likewise, Lipman (2013) stressed out that management practices concern respecting employees, providing employees appropriate training for the job, providing employees moral, technical and financial support, and showing effective leadership styles in the workplace. Presbitero et al. (2016) supported that management practices, especially on the human resource areas like reward management and training and development, can yield a positive and significant change in the level of employee engagement (Owoeye et al., 2020).

Employee engagement is something being given by an employee that can benefit the entire organization (Agyemang \& Ofie, 2013). It can be dedication, discretionary efforts, and being supportive of the organization's goals and objectives. Engaged Employees feel a sense of attachment towards their organization, investing themselves not only in their role but in the organization as a whole (Robertson-Smith \& Markwick, 2009). The group of “engaged" employees are highly committed to the organization, show a passion, and drive in their work (Sorenson \& Garman, 2013). They strive for excellence in their roles (Anitha, 2014).

Devi (2009) asserted that employee engagement is two-way interactions between the employee and the organization for which the organization has the accountability to show the way. The unique characteristics of an engaged workforce consist of loyalty, satisfaction, and encouragement. Thus, highly engaged employees have vigor, dedication, and absorption (Sonnentag, 2003).

However, when employees are disengaged, they lack the commitment to the jobs, poor job performance, does not communicate well in the organization, lack of motivation, and resistance to better alternatives. Moreover, management should check these employees for they cause lower productivity due to error and defects in performance (Sturt \& Nordstrom, 2018; Juevesa et al., 2020). Thus, management should see to it that they had appropriate practices to prevent employees from being not committed and disengaged (Kular et al., 2008).

Thus, this study was conducted to understand the lived experiences of the rank-and-file employees with regards to their management practices and their coping mechanisms to remain engaged with their jobs in the organization.

\section{Purpose of the Study}

The purpose of the study was to describe how employee experiences management practices in their workplace and their coping mechanisms to maintain their work engagement. This study involved the rank-and-file employees of medium enterprises in General Santos City, intending to gain an understanding of 
how they remain engaged with their jobs after experiencing the type of management practices they had in the organization.

This study also foresaw to record down experiences of employees about their administration management practices that would likely affect their employee engagement. This phenomenological study presented pieces of evidence about the employees' lived experiences in the workplace in coping with the kind of management practices their organization had. Moreover, it highlighted insights to management on how to substantiate appropriate practices leading to employees' high level of engagement.

In this study, the researcher intended to work closely, understand, listen, and grasp the stories as exposed by the participants while sharing their stands, challenges, struggles, or happiness as employees and how they coped up with the type of management do they had to remain engaged in the organization.

\section{Research Questions}

This study sought to answer the following questions:

1) What are the experiences of employees in the management practices of their organization?

2) How do employees cope up with the challenges of management practices to remain engaged with their jobs?

3) What insights to employee engagement could be drawn from the results of the study?

\section{Methodology}

\subsection{Research Design}

In this study, the researcher used qualitative-phenomenological research of Colaizzi (1978) focusing on job engagement as a result of management practices as experience by the rank-and-file employees of medium enterprises in General Santos City.

Qualitative research is about understanding and developing explanations of social phenomena (Hancock, Ockleford, \& Winridge, 2009). It is about answering what, how, and why to explore and understand development and behavior (Berk et al., 2015). Additionally, Radu (2019) stated that qualitative research is about obtaining data through open-ended and conversational communication.

According to Campbell \& Scott (2011), Creswell (2007), and Willis (2007), the qualitative-phenomenology is concerned with the human perceptions of phenomena of actual happenings in real-world situations. Moreover, it is about the belief and feelings of an individual's lived experiences (Aspers, 2015). It is an approach about a particular group lived experiences where the purpose is about describing a particular phenomenon (Creswell \& Poth, 2017; Maxwell, 2013).

In the context of this study, the qualitative phenomenological approach was used because it is an appropriate device to get a clear comprehension of human 
experiences, and grasping their thoughts, actions, and feelings to gain insights from their experiences. This method presented the specific details of experiences and how they are perceived by the subjects in the situation. Besides, through this approach, the experiences of the participants were explored specifically about their job engagement as a result of the workplace management practices.

\subsection{Role of the Researcher}

The concept of employee engagement is always taken into consideration in managing people in the workplace. Whether an employee is an executive, top or middle manager, rank and file employees, or an outsource one. Employee engagement is something to be dealt with to ensure organizational success.

This study focused on employee engagement among rank-and-file employees of the medium enterprises in General Santos City. The study used the qualitative-phenomenological approach in the scientific investigation of the phenomenon. Thus, in the process, the researcher was the research instrument itself in the conduct of the study. Meaning, the researcher was purely an investigator in gathering data from the participants (Giorgi, 2009).

The gathering of the data was done specifically through an in-depth interview (Locke et al., 2009; Suter, 2012). In-depth interview is a qualitative research technique that involves conducting intensive individual interviews with a small number of respondents to explore their perspectives on a particular idea, program, or situation (Boyce \& Neale, 2006). Through that method, the researcher examined and scrutinized the phenomena through the participants' lived experiences (Creswell \& Creswell, 2017). Thus, important features can be drawn, display and verified (Hancock et al., 2009).

\subsection{Participants of the Study}

Before the study was conducted, the researcher highly considers that the participants were someone who had the willingness who can give a detailed description of their lived experiences on management practices and their engagement status as based on the criteria identified by Richards \& Morse (2007) \& Saunders (2012). Thus, referrals from personal and professional networks of the researcher were considered. The organizations where they were working were double-checked at the Department of Trade and Industry (DTI) to assure that it belonged to the classification of medium enterprises in General Santos City.

Fifteen (15) participants were initially listed down but six (6) were chosen based on diverse backgrounds (Ghafoury et al., 2020) which were according to Creswell's (2006) suggestions of 5 - 25 individuals. The number was enough to gather information through conducting an in-depth interview or focus group discussion where unique information from the same phenomenon can be dissected and outlined. Moreover, as stated by Englander (2012), the researcher in qualitative research pursues knowledge by understanding the phenomenon through deeply penetrating their inner core of thoughts. 
In the study, the participants as presented in Table 1 took an hour during the in-depth interview where the researcher assured that essentials themes were captured and well-defined.

As shown on the table above, all participants were rank-and-file employees. They come from varied ages, sexes, industry where they are working and the position that they are handling. This is to assure that enough information will be captured in accordance to their own lived experiences.

This is to be noted further that the number of years that they are working in the industry was not considered. This is in consideration that management practices are consistently applied regardless whether the workers are new or old. Besides, enriched insights can be taken on how the new and old employees undertake work engagement.

Generally, the participants may have different job demands or organizational mission but all of them experiences management leadership and styles which can be of great insights to identify their engagement mechanisms in the workplace.

\subsection{Data Collection}

In the collection of the data for the study, the researcher conducted an in-depth interview with the 6 participants which include note-taking and audio-video recording.

An in-depth interview was the approach undertaken to elicit participant's vivid perspectives on the research topic (Mack et al., 2005). It was done rigorously to ensure the reliability and validity of the important ideas on qualitative research (Noble \& Smith, 2015).

Ethical consideration was insured before the actual in-depth interview was conducted among the participants. The key principles of ethical issues by Mack et al. (2005) \& Kaiser (2009) that consent, and confidentiality shall be obtained and observed. Dicicco-Bloom \& Crabtree (2006) further explained that rapport is an essential component of the interview. The preliminary meeting had been done before the actual interview to explain the details of the study. Written consent was also asked as evidence that they agreed and understood the process of the research. A safe and comfortable environment was also provided to avoid distractions and inferiority to the participants.

Table 1. The profile of the participants.

\begin{tabular}{ccccc}
\hline Participant No. & Age & Sex & Nature of the Organization & Position \\
\hline 1 & 30 & Female & Lending Company & Cashier \\
2 & 28 & Male & Rural Bank & Teller \\
3 & 29 & Male & Mall Employee & Encoder \\
4 & 37 & Female & School & Office Clerk \\
5 & 40 & Male & Manufacturing Company & Checker \\
6 & 25 & Female & Food Chain & Inventory Clerk \\
\hline
\end{tabular}


The data collection process, in general, assured that the principle of listening and deeper understanding was applied. It is to ensure that the participants will freely unveil their feelings and lived experiences of the discussed matters. Besides, the researcher's interest and focus on the field accompanied by recording and note-taking made the research process a successful one.

\subsection{Analysis of Data}

Considering this is a phenomenological study, the analysis of the data was done using Colaizzi's method. According to Colaizzi (1978) in Edward \& Welch (2011), the Collaizi's method has seven (7) steps, namely: transcribing all the subjects' descriptions; extracting significant statements that directly relate to the phenomenon under investigation; creating formulated meanings; aggregating formulated meanings into theme clusters; developing an exhaustive description which is a comprehensive description of the experience as articulated by the participants; identifying the fundamental structure of the phenomenon; and returning to participants for validation. These steps were also cited by Sanders (2003).

With the aforementioned steps, responses through the transcriptions were analyzed for significant meanings through open coding, categorizing meanings through axial coding, clustering, identifying emergent theme or themes, and lastly, coming up with a narrative out of the findings supported by pieces of literature and studies done by varied authors concerning management practices and employee engagement which necessitate discussions and interpretations of the phenomenon based on the subjects' lived experiences.

\subsection{Locale of the Study}

This study focused on the rank-and-file employees of medium enterprises in General Santos City.

General Santos City is the southernmost city in the Philippines. It was classified as a highly urbanized city and the fifteenth (15th) most populous city in the country. It is part of the SOCCSKSARGEN (South Cotabato, Sultan Kudarat, Sarangani, General Santos City) region and geographically located in the province of South Cotabato. The city's major economic activity is primarily anchored in the agro-industry and fishing industry. The city has more than 1000 newly registered medium to large enterprises (www.gensantos.gov.ph) and more than 9,000 renewed business permits for the year 2019 (www.businessmirror.com.ph).

The locale of the study was chosen because the mentioned city contains medium enterprises where this study is focused on.

\subsection{Procedural Rigors}

To establish the study's trustworthiness founded on the established qualitative criteria, the concepts of credibility (truth value), transferability (applicability), dependability (consistency), and confirmability (neutrality) was described (Krefting, 
1991). Strategies that the researcher used to enhance the value of the study regarding these concepts were presented as follows: credibility, this is about the adoption of well-established method, familiarity with the culture of participating organizations, tactics to ensure participants' honesty, iterative questioning, researcher's reflective commentary, member checks, thick description of the phenomenon under scrutiny, and examination of previous research findings were used by the researcher to establish confidence for the accurate recording of the phenomenon; transferability-this is about the concept that the findings of the study can be applied to other situations. Even though the participants are small and unique but the results can be a representation of the broader group; dependability - this is about the idea that if the study will be repeated in the same perspective, with the same process, and with similar contributors, parallel results will be gained; and confirmability-this is about the assurance of objectivity that the results of the study comes from the lived experiences of the participants and not from the perspectives of the researcher.

\subsection{Ethical Considerations}

The researcher observed ethical principles in the conduct of the research. According to Cohen et al. (2007), these ethical principles concern: not harm the participants-this study safeguard against doing anything that will harm the participants and the interview was conducted democratically; privacy and anonymity - the researcher remove the identifying information concerning the participants. In any case, that information was made public, guaranteed that permissions had been sought from the participants; confidentiality-the researcher was responsible to keep the learned information confidential. Nothing in this study harmed the participants and the people within their organizations; informed consent-the study makes the participants informed about the nature of the study by providing complete information about the direction of the study. The participants have the freedom to withdraw from the interview if deemed necessary; rapport and friendship - the researcher provided an environment that is trustworthy and sensitive to the power they hold over the participants. The researcher also assured neutrality avoiding situations in which participants will think that they were friends with the researcher; intrusiveness-the researcher dealing focus only on the study conducted; inappropriate behavior-the researcher in any manner was not closed to the participants. The researcher remembered that he was bounded by the code of conduct to treat the participants with respect; data interpretation-the researcher analyzed data in a manner that avoids misstatements, misinterpretations, or fraudulent analysis; and data ownership and rewards-the researcher own the work generated and the results of the study can be used for the improvement of the concerned organization.

\section{Results and Discussion}

Presented in this section were the experiences of the study participants, their in- 
sights and discernments as well the concepts that emerged from the information gleaned through the focus group discussions. This was presented based on research questions identified:

From the data collected on the experiences of the studied participants, 5 main themes emerged as shown in Table 2. These themes helped the researcher determine which core ideas to report. These themes are:

Trusting Employees-On the interview conducted, most of the statements presented by the participants based on their experiences were that their management trusts them on the matters that relate to their jobs. They feel trusted on how the way they do their jobs; on assigning them with bigger responsibility and even on involving them with important matters in the organization. They reiterated that trusting is a good management practice that must be sustained by the administration. Moreover, this situation makes them highly engaged \& maximizes their fulfillment in their respective workplaces (Spence-Laschinger et al., 2002). Besides, building trust develops effective relationships among people in the organization (Reina \& Reina, 2000) thereby contributing to higher organizational success.

Clear Communication-The responses revealed that their management was good in terms of communication. Through proper communication, as an employee, they were aware of the things that were happening surrounding the organization. Through clear communication, they are made aware of the organizational vision and direction. Moreover, important matters were well-relayed to them appropriately and timely. This clear communication was revealed by the participants that it made them highly engaged in the workplace. Moreover, if clear communication was highly in-place in the organization, it fosters employee's personal growth and facilitates understanding in the organization (Choren, 2015). Interpersonal communication between employees and managers improves the success of workplace breastfeeding support (Anderson et al., 2015).

Table 2. Essential themes and thematic statements on employees experiences on management practices of their organization.

Thematic Statements
Major Themes
They let me do my job in my own way.
My manager is always asking about my opinions.
I am always tasked with bigger responsibility.
Our boss is talking to us about important matters.
I am trusted to meet deadlines.
My boss always appoints me when he's not around.
Our manager knows us well in assigning tasks.




\section{Continued}

The communication in the office is in place.

Our boss is giving memos.

My manager is talking to me when I committed a mistake. We set clear objectives.

Clear Communication We are always having a meeting.

Personal and business concerns are communicated on time.

Urgent matters and schedules are posted in the bulletin.

Information is relayed immediately.

Memo for important matters is disseminated immediately.

We are encouraged to help each other in the office.

I feel the spirit of family.

We establish goals as a group.

Teamwork and Collaboration

Inconsistencie of Policy

Implementation
When we commit a mistake, our boss also taking it as his mistakes.

I can say that we are cohesive in the office.

There is always a helping hand when I need it.

My officemates are supportive and helpful.

I feel accepted in the workplace.

I observed that some rules are not followed.

Our boss is too lenient.

The decision sometimes is changing.

The manuals sometimes are not followed.

The boss sometimes is breaking the rules.

They override our decision.

The imposition of discipline is inconsistent.

There is too much democracy and consideration.

There is too much sympathy.

There is too much consideration.

Sometimes they forgot to say, "thank you".

I feel my effort is not compensated.

Sometimes I lost my motivation.

I feel not acknowledged sometimes.

There are times that incentives were given late.

Lack of Recognition

There are moments they failed to acknowledge my accomplishment.

I feel that my effort is too much.

I want to be recognized.

I need to improve in the area of recognition.

I want an incentive for my job. 
Teamwork and Collaboration-The interview results presented that teamwork and collaboration were felt and promoted the way the management handles the organization. The employees expressed that support, cohesiveness, help, and acceptance in their respective workplaces made them highly engaged with their jobs in the organization. Driskell et al. (2018) stated that teamwork is about the process by which team members collaborate for the attainment of organizational goals. It is an activity in which team outputs such as team effectiveness and satisfaction were created. Furthermore, collaboration helps build trust and manage conflict (Chiocchio et al., 2011).

Inconsistency of Policy Implementation-Based on the responses of the participants as reflected in this study, they presented their experience about the inconsistent policy implementation in the workplace. There were instances where rules were not followed, considerations were too much, and even there were also breaking and overriding decisions by the authority. They were very honest that they dislike these practices considering it leads to leniency and mediocrity of some office workers in doing with their jobs. According to Baron \& Kreps (1999), managing human resources needs the role of consistency and it is valuable for the employee. It is to be noted that sound company policies and their proper implementation provide confidence to the employee that they would not be discriminated and was found to have an impact to employee engagement (Abraham, 2012).

Lack of Recognition-The responses revealed that there were problems among employees in terms of recognition in the workplace. They presented that they were working enough; however, instances occur that they feel unrecognized by the management. They stressed out that recognition needs thorough attention by the management. It will add-on to the level of engagement they had to the organization. As stated by Brun \& Dugas (2008) employee recognition is a management issue and is considered as a basic need of an individual. Additionally, Bradler et al. (2016) stated that recognition leads to an increase in employee performance especially if it is given to the best performers.

Despite the experience by rank-and-file employees on management practices, they practice their mechanisms to cope with the challenges of the identified management practices. Based on the in-depth interview conducted, 4 essential themes emerged as revealed in Table 3. These are:

Acceptance of Organizational Culture-The employees resorted to accepting their organizational culture as a way to cope up with the management practices. They stressed out that every organization is unique and cannot be compared to each other. They saw the good management practices and those practices which they feel to be corrected in their organization. As an employee they were very honest that they loved their job and well-blessed to have it, that's why they cope up to remain engaged by way of accepting that this is the culture of the organization that they are working with. By knowing the organizational culture is crucial for a company's success (Pell, 2019). This is to be noted that leadership and 
Table 3. Themes and thematic statements of employees in coping up with the challenges of management practices to remain engaged with their jobs.

\begin{tabular}{|c|c|}
\hline Major Themes & Thematic Statements \\
\hline \multirow{10}{*}{$\begin{array}{l}\text { Acceptance of } \\
\text { Organizational } \\
\text { Culture }\end{array}$} & I stretch my patient to understand my boss and the company. \\
\hline & I need my job, so I need to accept the office culture and politics. \\
\hline & I know that every organization is unique. \\
\hline & Business by nature is incomparable. \\
\hline & I tried to understand the way things run in the office. \\
\hline & This is the culture; I need to accept it. \\
\hline & This is the system; thus, I need to embrace it. \\
\hline & I understand the company, my boss, and the people around me. \\
\hline & I stay if you can stay. \\
\hline & I will resign if I do not want the system. \\
\hline \multirow{10}{*}{$\begin{array}{l}\text { Presence of Family } \\
\text { Support }\end{array}$} & My family is my strength. \\
\hline & I love my family. \\
\hline & I need to support my family; I need this job. \\
\hline & I am talking to my wife and always open to her. \\
\hline & The important thing is, I have my job. \\
\hline & I am working for my family. \\
\hline & I am always thinking about the needs of my children. \\
\hline & My wife is my moral supporter. \\
\hline & I can financially support my parents because of this job. \\
\hline & My wife and children give me strength. \\
\hline \multirow{8}{*}{$\begin{array}{l}\text { Proactive Thinking } \\
\text { and Self-Motivation }\end{array}$} & I motivate myself too. \\
\hline & I just focus on the positive thing about my job. \\
\hline & I am looking that management will improve in the future. \\
\hline & My boss is also adjusting the way I observed. \\
\hline & The important is I am doing my best. \\
\hline & I need to do my best although others are not. \\
\hline & I need to do my job religiously. \\
\hline & I am paid for this job; I need to be good. \\
\hline
\end{tabular}

I know I am contributing positively to this job.

I always love my job.

I do not want to leave anymore and find another job.

Job Focus and Commitment
I want to stay here, this time; it is difficult to look for another job.

This job is an opportunity for me to work.

I stay this long because I just look upon the bright side of doing my job.

I must stay focused.

Job is a blessing, I must stay focused, and love it. 
organizational culture is a tool that can be used to better shape the dynamics of organization and change (Schein, 2010).

Presence of Family Support-To cope up with the management practices and to remain engaged with the jobs, the employees prefer to seek their family support. They voice out that it's the presence of their family is the one giving them the strength to continue doing positively for the job. Moreover, they continue engaging with the job because it's the source of their income and because of this; they were able to provide the needs of their family. In fact, because of family support, employees were able to cope up with their burnout (Baruch-Feldman et al., 2002). Besides, it's the family support that gives life satisfaction (King et al., 1995) regardless of the status that we had in the workplace. Moreover, it's the family support that mediates that job embeddedness to have creative job performance (Karatepe, 2016). Evidently, on frontline employees with sufficient family support they had been seen to be highly engaged with their jobs resulting in good job performance (Karatepe, 2015).

Proactive Thinking and Self-Motivation-By becoming proactive and selfmotivated were ways for employees to remain engaged in the organization. This was enormously the thought presented by the participants during the in-depth interview conducted. Those things in the organization that they are not in agreement on the way the management is doing, as employees they are stretching their patience to understand and hoping that things will change in the future. The important is they are doing what is expected of them as an employee of the organization. As stated by Parker (2001) proactive workforce is necessary for competitive advantage while Salanova \& Schaufeli (2008) cited that proactive behavior at work produces job engagement. Moreover, the self-motivation among employees drives forward the organization and it has a significant relationship for his job satisfaction and job performance (Aloysius, 2012).

Job Focus and Commitment-As coping mechanisms for job engagement, employees boldly stated that they resorted to having job focus and commitment in the organization. They prefer to work positively by looking into factors that will encourage them. As employees, they look into their jobs as something to be loved and cared about regardless of the negativity and frustrations. Focusing on the job gives employees enough attention to be more detailed on the assigned task (Caspi \& Reid, 2002). Likewise, those employees with job focus are less prone to burnout (Pala \& Tepeci, 2016). Whereas the commitment is about the employees' feeling of staying inside the organization (Meyer \& Allen, 1997), it is how an individual perceived of being engaged in the organization regardless of the environmental factors. Some might stay because they loved their jobs, obligated to stay in the job, or do not want to let go of the things that they are enjoying in their jobs (Juevesa \& Castino, 2020).

Employee engagement is something that management should care about. From the in-depth interview conducted, insights can be drawn by which management looks into to seek employee engagement. Thus, 4 themes emerged as 
detailed in Table 4. The following are as follows:

Valuing Employee-As stated by the participants, they believe that making employees highly engaged in the workplace valuing them is important. Letting employees feel that they were valued increases their morale thereby contributing more to the attainment of organizational objectives. This idea was supported by Mayhew (n.d.) that the most effective strategy of valuing employees can be through tangible and intangible rewards and recognition. By doing so the employees will go beyond and above the expected performance, they may even hold themselves accountable to achieve organizational objectives (Hall, 2013).

Table 4. Themes and core ideas on insights worth sharing to management increase to employee engagement.

\begin{tabular}{|c|c|}
\hline Major Themes & Thematic Statements \\
\hline \multirow{8}{*}{ Valuing Employee } & I let my employees feel that they are important. \\
\hline & I let my employees feel that they are trusted. \\
\hline & I teach my employee. \\
\hline & I mentor my employee. \\
\hline & I have control over their job. \\
\hline & To them, simple recognition will do. \\
\hline & I challenge and trust my employees that they can do great. \\
\hline & In the management, I make sure that they are connected. \\
\hline \multirow{8}{*}{$\begin{array}{l}\text { Leadership by } \\
\text { Example }\end{array}$} & They show us what to do. \\
\hline & We follow what they are doing. \\
\hline & My boss somehow influences me. \\
\hline & If I were the head, I want to inspire my workers. \\
\hline & I do not cause stress to my co-employee. \\
\hline & A boss with action is good. \\
\hline & I like my boss because he sets an expectation. \\
\hline & I do not want a boss who is good at talking. \\
\hline \multirow{7}{*}{$\begin{array}{l}\text { Proper Channel of } \\
\text { Communication }\end{array}$} & I let them know immediately about the issue. \\
\hline & I let them talk to us directly. \\
\hline & We are always reminded about important matters. \\
\hline & Memorandums are circulated. \\
\hline & We are always aware through the bulletin. \\
\hline & Personal attention is given. \\
\hline & Concerns are thrown to us directly. \\
\hline \multirow{8}{*}{$\begin{array}{l}\text { Authentic Management } \\
\text { Recognition }\end{array}$} & Sincere appreciation is enough. \\
\hline & Expressing gratitude is vital to the employees. \\
\hline & Giving credit to whom credit is due always a practice. \\
\hline & A culture of recognition is better. \\
\hline & My boss encourages feedback. \\
\hline & Rewards those who are worthy. \\
\hline & The principle of giving incentive is clear. \\
\hline & It is good to foster a culture of recognition. \\
\hline
\end{tabular}


Leadership by Example-Managers in the organization is expected to be of a great leader and serve as an example to employees both in words and indeed. This boldly expressed by the participant as an insight to management trying to win employee engagement. Through leadership by example, employees are inspired to follow what they have seen and observed. In the study conducted by Qiu et al. (2018), it was found out that leading by example and personal traits have positive effects on followers' cooperation. Moreover, leading by example has effects on the organizational behavior of the group inside the organization (Yaffe \& Kark, 2011). Thus, it positively contributing to the attainment of organizational goals.

Proper Channel of Communication-One of the insights given by the participants for management improvement to encourage engagement among employees was about a proper channel of communication. The proper channel of communication makes them aware of the things and situations happening inside the organization. Balakrishnan \& Masthan (2013) stated that internal communication in the organization has a direct relationship to employee engagement. In that, a two-way communication process should be given attention to motivate employees towards their work by executing a specific engagement plan and creating an inclusive environment to achieve a higher confidence level and enthusiasm among them (Jha \& Kumar, 2016; Sundaray, 2011).

Authentic Management Recognition-The participants explained that management recognition can be a tool for employee engagement. If management had the authentic way of recognizing employees, it would boost their confidence and morale to do more in the organization. This motivation will lead the employee to become more productive and efficient in the workplace. White (2015) said that authentic recognition not only makes employees feel about, it has also a financial impact on the organization where employees strive to makes the organization competitive. Zielinski (2018) believes that if the company applies meaningful employee recognition, they were able to retain their best employees and always keeping pace with the competitors.

\section{Summary}

The results of the study during the in-depth interview conducted revealed that rank and file employees experience the management practices of trusting employees; clear communication; teamwork and collaboration; inconsistency of policy implementation; and lack of recognition. The discussion deeply circulated that the said experiences can cause engagement or disengagement of the employees in the workplace.

The participants also were vocal that maintaining engagement is necessary for the workplace. Even though management practices need to elicit engagement but employees prefer to cope up with through: acceptance of organizational culture; the presence of family support; proactive thinking and self-motivation; and job focus and commitment. However, there were two (2) participants who were 
very honest in admitting that sometime they may feel disengage but they believe that it is just a positive personal perception by looking into things that it can be change and improve in the future.

The study further showed that management practices should be aligned to solicit employee engagement. Thus, the following insights that can be considered are: valuing employees; leadership by example; proper channel of communication; and authentic management recognition. Participants expressly stated that by applying such practices, it will increase engagement in the organization.

\section{Implications for Practice}

Based on the findings of the study, the following implications for practiced are offered:

On the management practices as experienced by the rank-and-file employees. The experiences presented by the employees in this study are observed to be of positive and negative experiences. The negative experiences like the inconsistency of policy implementation and lack of recognition can be a lesson to the management by way of revisiting their management practices, policies, and culture. If management wants to encourage employee engagement, their practices should also be aligned in a way that will boost the morale of the employees in the organization.

On the employees coping mechanisms to engagement. It has been established that work engagement is also a personal perception of the individual in his job regardless of the management practices. It was stressed out that employees should know the type of management do the organization had to avoid disengagement and demotivation. The coping mechanisms identified are effective enough for employees in helping their management in shaping the right management practices that should be applied in the workplace.

On the insights for employee engagement. It is to be noted that employee engagement is one of the factors that needs thorough attention by the management. By having the right strategies in handling human capital, the more that it can contribute positively to the organization. The insights presented that come from the rank-and-file employees is an opportunity for the management to improve their management practices. By doing so, a better employer and employee relationship are in place.

\section{Limitations of the Research}

This study is qualitative-phenomenological research where data was gathered based on participants personal lived experiences. The insights gathered might not be the representation of the whole population of the rank-and-file employees.

Moreover, this study was conducted in medium enterprises. Their experiences might be different from employees of micro, small and large enterprises. This is to be noted further that there might be a unique work environment in General 
Santos City which can affects the management practices and employee's engagement in the workplace.

\section{Implications for Future Research}

In as much as the management practices and employees engaged in this study were limited in General Santos City, the following implication for future research may be done:

Since the phenomenological study presents pieces of evidence on management practices and employee engagement of the rank-and-file employees, it could be probable to conduct qualitative research about the effects of leadership styles; job commitment; organizational citizenship; job satisfaction, etc. among the rankand-file employees and know their lived experiences about it.

Moreover, the findings of the study were taken from the perspective of the rank-and-file employees of medium enterprises, thus, another research like the top and middle managers of a large corporation; rank and file in the government offices; or owner of small enterprises could be a legitimate venture to the lookout.

\section{Concluding Remarks}

The investigation on the lived experiences of rank-and-file employees in terms of management practices and employee engagement has highlighted the significance of the study. The results mentioned can be taken into consideration by the existing medium enterprises and can serve as baseline information for organizational innovation. However, prudence is also suggested considering organizational uniqueness where one practice might not be necessarily applicable to other organizations. Moreover, this is taken directly from the personal view of the participants and it might not be necessarily representing the actual scenario of the organization.

However, the results of the study cannot be neglected because the qualitative research method is better at bringing to surface human perceptions for it is based on actual experiences and gathered through in-depth interviews where participants relive the essence of the said experiences (Starks \& Trinidad, 2007).

Thus, the study about management practices and employee engagement have left insights about valuing employee, leadership by example, the proper channel of communication, and authentic management recognition.

\section{Acknowledgements}

The authors commend the support of the administration of Ramon Magsaysay Memorial Colleges (RMMC) in the conduct of the study. They also acknowledge the time and effort given by the participants during the research process. Lastly, an appreciation to all the faculty members of the BS in Accountancy program for the moral and technical support. 


\section{Conflicts of Interest}

The authors declare no conflicts of interest regarding the publication of this paper.

\section{References}

Abraham, S. (2012). Job Satisfaction as an Antecedent to Employee Engagement. SIES Journal of Management, 8, 27-36.

Agyemang, C. B., \& Ofie, S. B. (2013). Employee Work Engagement and Organizational Commitment: A Comparative Study of Private and Public Sector Organizations in Ghana. European Journal of Business and Innovation Research, 1, 20-33.

Aloysius, S. M. C. M. (2012). Self Motivation for Achievement and Its Impact for on the Employees Performance and Satisfaction. SSRN Electronic Journal. https://papers.ssrn.com/sol3/papers.cfm?abstract_id=2186389 https://doi.org/10.2139/ssrn.2186389

Anderson, J., Kuehl, R. A., \& Mehltretter-Drury, S. A. (2015). Policies Aren't Enough: The Importance of Interpersonal Communication about Workplace Breastfeeding Support. Journal of Human Lactation, 31, 260-266. https://doi.org/10.1177/0890334415570059

Anitha, J. (2014). Determinants of Employee Engagement and Their Impact on Employee Performance. International Journal of Productivity and Performance Management, 63, 308-323. https://doi.org/10.1108/IJPPM-01-2013-0008

Aspers, P. (2015). Empirical Phenomenology: A Qualitative Research Approach (The Cologne Seminars). Indo-Pacific Journal of Phenomenology, 9, 1-12. https://doi.org/10.1080/20797222.2009.11433992

Balakrishnan, C., \& Masthan, D. (2013). Impact of Internal Communication on Employee Engagement-A Study at Delhi International Airport. International Journal of Scientific and Research Publications, 3, 1-13. http://www.ijsrp.org/research-paper-0813/ijsrp-p2059.pdf

Baron, J. N., \& Kreps, D. M. (1999). Consistent Human Resource Practices. California Management Review, 41, 29-53.

Baruch-Feldman, C., Brondolo, E., Ben-Dayan, D., \& Schwartz, J. (2002). Sources of Social Support and Burnout, Job Satisfaction, and Productivity. Journal of Occupational Health Psychology, 7, 84-93. https://doi.org/10.1037/1076-8998.7.1.84

Berk, M., Otmar, R., Dean, O., Berk, L., \& Michalak, E. (2015). Chapter 6. The Use of Mixed Methods in Drug Discovery: Integrating Qualitative Methods into Clinical Trials. In M. Tohen, C. L. Bowden et al. (Eds.), Clinical Trial Design Challenges in Mood Disorders (pp. 59-74). Cambridge, MA: Academic Press. https://doi.org/10.1016/B978-0-12-405170-6.00006-3

Boyce, C., \& Neale, P. (2006). Conducting In-Depth Interview: A Guide for Designing and Conducting In-Depth Interviews for Evaluation Input. In Pathfinder International Tool Series, Monitoring and Evaluation-2. Pathfinder International.

http://www2.pathfinder.org/site/DocServer/m_e_tool_series_indepth_interviews.pdf?d ocID $=6301$

Bradler, C., Dur, R., Neckermann, S., \& Non, A. (2016). Employee Recognition and Performance: A Field Experiment. Management Science, 62, 3085-3391. https://doi.org/10.1287/mnsc.2015.2291

Brun, J. P., \& Dugas, N. (2008). An Analysis of Employee Recognition: Perspectives on 
Human Resources Practices. The International Journal of Human Resource Management, 19, 716-730. https://doi.org/10.1080/09585190801953723

Campbell, S., \& Scott, J. (2011). Process of Conducting Qualitative Research: Steve Campbell and John Scott Describe How This Issue's Themed Papers Contribute to the Debate on the Ethical Conduct of Qualitative Research. Nurse Researcher, 18, 4-6.

Caspi, J., \& Reid, W. J. (2002). Educational Supervision in Social Work: A Task-Centered Model for Field Instruction and Staff Development. New York: Columbia University Press. https://doi.org/10.7312/casp10852

Chiocchio, F., Forgues, D., Paradis, D., \& Iordanova, I. (2011). Teamwork in Integrated Design Projects: Understanding the Effects of Trust, Conflict, and Collaboration on Performance. Project Management Journal, 42, 78-91.

https://doi.org/10.1002/pmj.20268

Choren, A. (2015). The Importance of Communication in the Workplace. IEEE Potentials, 34, 10-11. https://doi.org/10.1109/MPOT.2014.2331793

Cohen, R., Manion, L., \& Morrison, K. (2007). Research Methods in Education (1st ed.). New York: Routledge Publication.

http://uk.sagepub.com/sites/default/files/upm-binaries/27011_4.pdf

Colaizzi, P. F. (1978). Psychological Research as the Phenomenologist Views It. In R. S. Valle, \& K. Mark (Eds.), Existential Phenomenological Alternatives for Psychology (pp. 48-71). New York: Oxford University Press.

Creswell, J. W. (2006). Qualitative Inquiry and Research Design: Choosing among Five Approaches (2nd ed.). Thousand Oaks, CA: SAGE Publications, Inc.

Creswell, J. W. (2007). Qualitative Inquiry and Research Design: Choosing among Five Approaches (3rd ed.). Thousand Oaks, CA: SAGE Publications, Inc.

Creswell, J. W., \& Creswell, J. D. (2017). Research Design: Qualitative, Quantitative, and Mixed Methods Approaches (5th ed.). Thousand Oaks, CA: SAGE Publications, Inc.

Creswell, J. W., \& Poth, C. N. (2017). Qualitative Inquiry \& Research Design: Choosing among the Five Approaches (4th ed.). Thousand Oaks, CA: SAGE Publications, Inc.

Devi, R. (2009). Employee Engagement Is a Two-Way Street. Human Resource Management International Digest, 17, 3-4. https://doi.org/10.1108/09670730910940186

Dicicco-Bloom, B., \& Crabtree, B. F. (2006). The Qualitative Research Interview. Medical Education, 40, 314-321.

Driskell, J. E., Salas, E., \& Driskell, T. (2018). Foundations of Teamwork and Collaboration. American Psychologist, 73, 334-348. https://doi.org/10.1037/amp0000241

Edward, K.-L., \& Welch, T. (2011). The Extension of Colaizzi's Method of Phenomenological Enquiry. Contemporary Nurse, 39, 163-171.

https://doi.org/10.5172/conu.2011.39.2.163

Englander, M. (2012). The Interview: Data Collection in Descriptive Phenomenological Human Scientific Research. Journal of Phenomenological Psychology, 43, 13-35. https://doi.org/10.1163/156916212X632943

Ghafoury, M., Roosta, A., \& Hajipour, B. (2020). A Phenomenological Study of Customer Disvalue. Iranian Journal of Management Studies, 13, 367-390.

Giorgi, A. (2009). The Descriptive Phenomenological Method in Psychology: A Modified Husserlian Approach. Pittsburgh: Duquesne University Press.

Hall, J. (2013). 5 Unique Ways to Invest In Your Employees. https://www.forbes.com/sites/johnhall/2013/07/15/5-unique-ways-to-invest-in-your-e mployees/\#2e1bd07c359f 
Hancock, B., Ockleford, E., \& Windridge, K. (2009). An Introduction to Qualitative Research (pp. 1-39). National Institute for Health Research.

http://www.rds-yh.nihr.ac.uk/wp-content/uploads/2013/05/5_Introduction-to-qualitati ve-research-2009.pdf

Henry, J. W. (1994). The Service Employee's Pivotal Role in Organizational Success. Journal of Services Marketing, 8, 25-35. https://doi.org/10.1108/08876049410070709

Jha, B., \& Kumar, A. (2016). Employee Engagement: A Strategic Tool to Enhance Performance. DAWN: Journal for Contemporary Research in Management, 3, 21-29.

Juevesa, R. D., \& Castino, J. M. P. (2020). Employees Engagement and Organizational Performance among Multigenerational Workforce in a Private Non-Sectarian School. International Journal of Science and Management Studies, 3, 41-56. http://ijsmsjournal.org/2020/volume-3\%20issue-4/ijsms-v3i4p105.pdf

Juevesa, R. D., Juevesa, C. V., \& Juevesa Jr., R. D. (2020). Corporate Strategy and Organizational Performance of Manpower Service Cooperative. SSRG International Journal of Economics and Management Studies (SSRG-IJEMS), 7, 106-125.

http://www.internationaljournalssrg.org/IJEMS/paper-details?Id=664 https://doi.org/10.14445/23939125/IJEMS-V7I7P114

Kaiser, K. (2009). Protecting Respondent Confidentiality in Qualitative Research. Qualitative Health Research, 19, 1632-1641. https://doi.org/10.1177/1049732309350879

Karatepe, O. M. (2015). The Effects of Family Support and Work Engagement on Organizationally Valued Job Outcomes. Institute of Tourism, 63, 447-464. http://www.researchgate.net/publication/296873469

Karatepe, O. M. (2016). Does Job Embeddedness Mediate the Effects of Coworker and Family Support on Creative Performance? An Empirical Study in the Hotel Industry. Journal of Human Resources in Hospitality \& Tourism, 15, 119-132. https://doi.org/10.1080/15332845.2016.1084852

King, L. A., Mattimore, L. K., King, D. W., \& Adams, G. A. (1995). Family Support Inventory for Workers: A New Measure of Perceived Social Support from Family Members. Journal of Organizational Behavior, 16, 235-258. https://doi.org/10.1002/job.4030160306

Kirkeby, O. F. (2000). Management Philosophy. A Radical-Normative Perspective. Berlin, Germany: Springer-Verlag.

Krefting, L. (1991). Rigor in Qualitative Research: The Assessment of Trustworthiness. American Journal of Occupational Therapy, 45, 214-222. https://doi.org/10.5014/ajot.45.3.214

Kular, S., Gatenby, M., Rees, C., Soane, E., \& Truss, K. (2008). Employee Engagement: A Literature Review. KBS Working Paper No. 19, Kingston Business School. https://eprints.kingston.ac.uk/4192/1/19wempen.pdf

Lipman, V. (2013). 7 Management Practices That Can Improve Employee Productivity. https://www.forbes.com/sites/victorlipman/2013/06/17/7-management-practices-that-c an-improve-employee-productivity/\#5cd3984d484c

Locke, L. F., Silverman, S. J., \& Spirduso, W. W. (2009). Reading and Understanding Research (3rd ed.). Thousand Oaks, CA: SAGE Publications, Inc.

Luenendonk, M. (2017). Management Practices. https://www.cleverism.com/lexicon/management-practices/

Mack, N., Woodsong, C., Macqueen, K. M., Guest, G., \& Namey, E. (2005). Qualitative Research Methods: A Data Collector's Field Guide. Research Triangle Park, NC: Family Health International. 
Manzoor, Q. A. (2012). Impact of Employees Motivation on Organizational Effectiveness. European Journal of Business and Management, 3, 36-45.

https://iiste.org/Journals/index.php/EJBM/article/viewFile/265/150 https://doi.org/10.5296/bms.v3i1.904

Maxwell, J. A. (2013). Qualitative Research Design: An Interactive Approach. Thousand Oaks, CA: SAGE Publications, Inc.

Mayhew, R. (n.d.). What Are Some Ways That a Company Can Value Its Employees? Small Business Managing Employees. https://smallbusiness.chron.com/ways-company-can-value-its-employees-44257.html

Medina, R. G. (2011). Human Behavior in the Organization. Manila, Philippines: Rex Book Store, Inc.

Meyer, J. P., \& Allen, N. J. (1997). Commitment in the Workplace. Thousand Oaks, CA: SAGE Publication, Inc.

Noble, H., \& Smith, J. (2015). Issues of Validity and Reliability in Qualitative Research. Evidence-Based Nursing, 18, 34-35.

http://eprints.hud.ac.uk/id/eprint/23995/1/SmithIssues.pdf

Owoeye, I., Kiiru, D., \& Muli, J. (2020). Recognition Practices and Employee Performance: Understanding Work Engagement as a Mediating Pathway in Kenyan Context. Journal of Human Resource Management, 8, 163-171. https://doi.org/10.11648/j.jhrm.201200803.17

Pala, T., \& Tepeci, M. (2016). The Effects of Job-Focused and Employee-Focused Emotional Labor on Burnout in the Hospitality Industry in Turkey. Research in Global Strategic Management, 10, 95-105.

Parker, S. (2001). From Passive to Proactive Motivation: The Importance of Flexible Role Orientations and Role Breadth Self-Efficacy. Applied Psychology, 49, 447-469. https://doi.org/10.1111/1464-0597.00025

Pell, R. (2019). How to Measure Your Organizational Culture and Values. https://surveyanyplace.com/organizational-culture-values/

Presbitero, A., Roxas, B., \& Chadee, D. (2016). Looking beyond HRM Practices in Enhancing Employee Retention in BPOs: Focus on Employee-Organisation Value Fit. The International Journal of Human Resource Management, 27, 635-652. https://doi.org/10.1080/09585192.2015.1035306

Qiu, H., Zhang, Y., Hou, G., \& Wang, Z. (2018). The Integrative Effects of Leading by Example and Follower Traits in Public Goods Game: A Multilevel Study. Frontiers in Psychology, 9, 1687. https://www.frontiersin.org/articles/10.3389/fpsyg.2018.01687/full https://doi.org/10.3389/fpsyg.2018.01687

Radu, V. (2019). Qualitative Research: Definition, Methodology, Limitation, Examples. https://www.omniconvert.com/blog/qualitative-research-definition-methodology-limit ation-examples.html

Reina, D. S., \& Reina, M. L. (2000). Trust and Betrayal in the Workplace: Building Effective Relationships in Your Organization. Advances in Developing Human Resources, 2, 121. https://doi.org/10.1177/152342230000200112

Richards, L., \& Morse, J. (2007). Read Me First for a User's Guide to Qualitative Methods. Thousand Oaks, CA: SAGE Publication, Inc.

Robertson-Smith, G., \& Markwick, C. (2009). Employee Engagement: A Review of Current Thinking. Brighton, UK: Institute for Employment Studies.

https://www.employment-studies.co.uk/system/files/resources/files/469.pdf

Salanova, M., \& Schaufeli, W. B. (2008). A Cross-National Study of Work Engagement as 
a Mediator between Job Resources and Proactive Behaviour. The International Journal of Human Resource Management, 19, 116-131. https://doi.org/10.1080/09585190701763982

Sanders, C. (2003). Application of Colaizzi's Method: Interpretation of an Auditable Decision Trail by a Novice Researcher. Contemporary Nurse Journal, 14, 292-302. https://doi.org/10.5172/conu.14.3.292

Saunders, M. (2012). Choosing Research Participants. In G. Symon, \& C. Cassell (Eds.), Qualitative Organizational Research (pp. 35-52). London: SAGE Publications, Inc. https://doi.org/10.4135/9781526435620.n3

Schein, E. H. (2010). Organizational Culture and Leadership (4th ed.). San Francisco, CA: Jossey-Bass.

Sonnentag, S. (2003). Recovery, Work Engagement, and Proactive Behavior: A New Look at the Interface between Nonwork and Work. Journal of Applied Psychology, 88, 518-528. https://doi.org/10.1037/0021-9010.88.3.518

Sorenson, S., \& Garman, K. (2013). How to Tackle U.S Employees' Stagnating Engagement.

http://businessjournal.gallup.com/content/162953/tackle-employees-stagnating-engage ment.aspx

Spence-Laschinger, H. K., Finegan, J., \& Shamian, J. (2002). The Impact of Workplace Empowerment, Organizational Trust on Staff Nurses' Work Satisfaction and Organizational Commitment. Advances in Health Care Management, 3, 59-85.

https://doi.org/10.1016/S1474-8231(02)03006-9

Starks, H., \& Trinidad, S. B. (2007). Choose Your Method: A Comparison of Phenomenology, Discourse Analysis, and Grounded Theory. Qualitative Health Research, 17, 1372-1380. https://doi.org/10.1177/1049732307307031

Sturt, D., \& Nordstrom, T. (2018). Performance Management: One Simple Secret for Doing It Right.

https://www.forbes.com/sites/davidsturt/2018/06/15/performance-management-1-sim ple-secret-to-do-it-right/\#30a372151981

Sundaray, B. K. (2011). Employee Engagement: A Driver of Organizational Effectiveness. European Journal of Business and Management, 3, 53-60.

Suter, N. (2012). Introduction to Educational Research: A Critical Thinking Approach (2nd ed.). Thousand Oaks, CA: SAGE Publications, Inc.

White, P. (2015). Improving Staff Morale through Authentic Appreciation. http://appreciationatwork-media.s3.amazonaws.com/uploads/2015/04/TD_White.pdf

Willis, J. (2007). Foundations of Qualitative Research: Interpretive and Critical Approaches. Thousand Oaks, CA: SAGE Publications, Inc. https://doi.org/10.4135/9781452230108

Yaffe, T., \& Kark, R. (2011). Leading by Example: The Case of Leader OCB. Journal of Applied Psychology, 96, 806-826. https://doi.org/10.1037/a0022464

Zielinski, D. (2018). Put Recognition in Your Employees' Hands Peer-to-Peer Recognition Is Most Effective-Especially When It's Easy to Do.

https://www.shrm.org/ResourcesAndTools/hr-topics/technology/Pages/HR-Recognitio n-Peer-to-Peer-Employees.aspx 